\title{
Kualitas Hidup Anak dengan Hemofilia di Rumah Sakit Dr. Cipto Mangunkusumo
}

Febrini Agasani, Soedjatmiko, Endang Windiastuti

Departemen Ilmu Kesehatan Anak Fakultas Kedokteran Universitas Indonesia/ Rumah Sakit Dr. Cipto Mangunkusumo Jakarta

Latar belakang. Hemofilia merupakan salah satu penyakit kronik yang dapat memengaruhi kualitas hidup.

Tujuan. Mengetahui prevalensi, gangguan kualitas hidup, kesesuaian kualitas hidup berdasarkan laporan anak dan laporan orangtua serta pengaruh faktor medis terhadap kualitas hidup anak hemofilia di RSCM.

Metode. Penelitian potong lintang pada pasien hemofilia usia 5-18 tahun di Poliklinik Hematologi Departemen Ilmu Kesehatan Anak RSCM selama September-Desember 2016. Pengisian kuesioner PedsQL ${ }^{\mathrm{TM}} 4.0$ dilakukan dengan wawancara. Faktor risiko dianalisis secara multivariat.

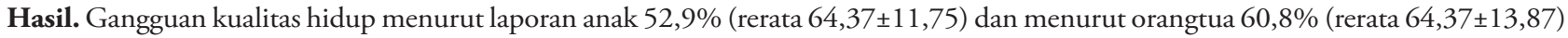
dari total 102 anak hemofilia. Dimensi yang paling terganggu adalah dimensi fisik menurut kelompok 5-7 tahun, sedangkan menurut kelompok 8-18 tahun adalah dimensi fisik dan sekolah. Terdapat ketidaksesuaian antara laporan kualitas hidup anak dan orangtua pada kelompok usia 5-7 tahun. Kekakuan sendi merupakan faktor risiko terjadinya gangguan kualitas hidup menurut laporan anak ( $\mathrm{p}=0,005$, RP 4,335, IK 95\% 1,550-12,126) dan orangtua ( $\mathrm{p}=0,04$, RP 2,902, IK 95\% 1,052-8,007).

Kesimpulan. Terdapat 52,9\% (laporan anak) dan 60,8\% (laporan orangtua) anak hemofilia yang kualitas hidupnya terganggu. Kekakuan sendi merupakan faktor yang paling memengaruhi kualitas hidup. Untuk menilai kualitas hidup anak usia 5-7 tahun diperlukan laporan anak dan orangtuanya, sedangkan anak usia 8-18 tahun cukup laporan anak atau orangtua saja. Sari Pediatri 2019;21(2):73-80

Kata kunci: kualitas hidup, hemofilia, anak

\section{Quality of Life Children with Hemophilia in Dr. Cipto Mangunkusumo Hospital}

Febrini Agasani, Soedjatmiko, Endang Windiastuti

Background. Hemophilia is a chronic disease that can affect quality of life (QoL).

Objective. To evaluate the prevalence, QoL, congruence of QoL based on self-report and parents-proxy report as well as the influence of sociodemographic and medical factors on the QoL of children with hemophilia in CMH.

Method. A cross-sectional study was conducted in patients with hemophilia aged 5-18 years old who visited the outpatient clinic of Pediatric Hematology Division of CMH from September to December 2016. Data questionnaire PedsQL ${ }^{\mathrm{TM}} 4.0$ were collected by interviewing children and their parents. Risk factors were analyzed with multivariate analysis.

Result. From a total of 102 children with hemophilia, there were $52.9 \%$ (self report) and $60.8 \%$ (parent-proxy report) of children with impairment of QoL with mean score $64.37 \pm 11.75$ and $64.37 \pm 13.87$, respectively. The most impaired dimension was the physical dimension for age group 5-7 years whereas for age group 8-18 years, there was impairment on the physical and school dimensions. There is a discrepancy report the QoL of children and parents in the age group 5-7 years. Joint stiffness is a risk factor for impaired QoL according to the self report ( $\mathrm{p}=0.005$, PR 4.335, 95\% CI 1.550 to 12.126$)$ and parent-proxy report ( $\mathrm{p}=0.04, \mathrm{PR} 2.902,95 \%$ CI 1.052 to 8.007$)$.

Conclusion. There were $52.9 \%$ (self report) and 60.8\% (parent-proxy report) of children with hemophilia who had impaired QoL. Joint stiffness is a factor that mostly affects the QoL of children with hemophilia. Assessment of QoL for children aged 5-7 years required reports from both children and parents, while for aged 8-18 years required either child report or the parents report alone. Sari Pediatri 2019;21(2):73-80

Keywords: quality of life, hemophilia, children

Alamat korespondensi: Febrini Agasani. Departemen Ilmu Kesehatan Anak Fakultas Kedokteran Universitas Indonesia- RSCM Jl. Salemba no. 6, Jakarta 10430. Email: febriniagasani@gmail.com. 
$\mathrm{H}$ emofilia merupakan salah satu penyakit kronik yang memengaruhi kualitas hidup penderitanya. Penilaian kualitas hidup merupakan parameter untuk mengetahui keberhasilan pengobatan yang diberikan dari sudut pandang pasien. Penilaian kualitas hidup pasien penyakit kronik, seperti hemofilia, berguna untuk deteksi pasien yang memiliki kesulitan terkait penyakit hemofilia yang dideritanya, memperkirakan masalah-masalah terkait penyakit hemofilia, dan menentukan pengobatan yang holistik dan memuaskan. ${ }^{1}$ Kualitas hidup pasien hemofilia berbeda disetiap daerah. ${ }^{2}$ Belum ada penilaian kualitas hidup anak dengan hemofilia di Indonesia, khususnya di Jakarta. Penelitian ini bertujuan untuk mengetahui kualitas hidup anak dengan hemofilia yang datang ke Poliklinik Hematologi di Departemen IKA RSCM.

\section{Metode}

Uji potong lintang dilakukan pada anak usia 5-18 tahun yang menderita hemofilia A dan B di Poliklinik Hematologi IKA RSCM selama September-Desember 2016. Pengisian kuesioner PedsQL ${ }^{\mathrm{TM}} 4.0$ modul generik dilakukan dengan metode wawancara oleh peneliti dengan anak dan peneliti dengan orangtua. Data lain yang diambil adalah faktor sosiodemografis (usia saat didiagnosis, pendidikan orangtua, pendapatan orangtua, lokasi tempat tinggal, dan lama menderita hemofilia) dan faktor medis (derajat keparahan penyakit, ada tidaknya inhibitor, frekuensi perdarahan sendi, frekuensi kunjungan ke rumah sakit dan ada tidaknya kekakuan sendi).

Skor $<70$ menunjukkan kualitas hidup terganggu dan $\geq 70$ menunjukkan kualitas hidup baik. Usia pasien dikelompokkan berdasarkan usia kuesioner PedsQL ${ }^{T M}$, yaitu 5-7, 8-12, dan 13-18 tahun. ${ }^{3}$ Lama menderita hemofilia dihitung dari usia perdarahan pertama kali hingga usia saat ini dan dinyatakan dalam tahun. Derajat keparahan penyakit dibagi berdasarkan kadar faktor VIII atau IX dalam darah, yaitu ringan $(<1 \%)$, sedang $(1-5 \%)$, dan berat $(>5 \%){ }^{4}$ Frekuensi perdarahan sendi adalah banyaknya episode perdarahan sendi yang terjadi dalam satu tahun terakhir. Frekuensi kunjungan ke rumah sakit adalah banyaknya kunjungan ke Poliklinik Hematologi IKA RSCM karena perdarahan. Anak dikelompokkan ada kekakuan sendi berdasarkan keluhan keterbatasan pergeraan sendi tanpa memperhatikan tipe range of motion (ROM).

Pengolahan data dengan analisis bivariat variabel kategorik menggunakan uji Chi-Square dan uji Fisher bila tidak memenuhi kriteria. Analisis bivariat variabel numerik menggunakan uji t- tidak berpasangan dan uji alternatif Mann-Whitney jika tidak memenuhi kriteria. Analisis yang digunakan untuk analisis multivariat ditentukan berdasarkan variabel terikat. Oleh karena variabel terikat merupakan skala nominal, digunakan regresi logistik.

\section{Hasil}

Selama kurun waktu penelitian didapatkan 102 anak yang memenuhi kriteria penelitian. Semua subyek berjenis kelamin lelaki, mendapatkan terapi on-demand dan pembiayaan menggunakan Badan Penyelenggara Jaminan Sosial (BPJS). Kriteria subyek penelitian tertera pada Tabel 1.

Berdasarkan laporan anak didapatkan 52,9\% mengalami gangguan kualitas hidup, sedangkan menurut laporan orangtua sebanyak $60,8 \%$ mengalami gangguan kualitas hidup. Fungsi fisis merupakan gangguan kualitas hidup tertinggi menurut laporan anak dan orangtua. Perbandingan dimensi kualitas hidup berdasarkan laporan anak dan orangtua tertera pada Gambar 1.

Kualitas hidup anak hemofilia berdasarkan usia tertera pada Tabel 2. Fungsi fisis terganggu menurut laporan anak pada kelompok usia 5-7 tahun, sedangkan menurut laporan orangtua terganggu pada fungsi fisis dan sekolah. Ketidaksesuaian laporan anak dan orangtua terdapat pada fungsi emosi dan fungsi sekolah dengan nilai $\mathrm{p}<0,05$.

Laporan anak usia 8-12 tahun terganggu kualitas hidupnya pada fungsi fisis dan fungsi sekolah, sedangkan menurut laporan orangtua terganggu pada fungsi fisis, emosi, dan sekolah. Laporan anak dengan laporan orangtua sesuai pada kelompok ini.

Anak usia 13-18 tahun melaporkan gangguan kualitas hidup pada fungsi fisis dan sekolah. Gangguan kualitas hidup menurut laporan orangtua pada kelompok ini terdapat pada fungsi fisis, fungsi emosi, dan fungsi sekolah. Ketidaksesuaian laporan anak dan orangtua kelompok ini ditemukan pada fungsi fisis $(\mathrm{p}<0,05)$. 
Tabel 1. Karakteristik subyek penelitian

\begin{tabular}{|c|c|c|c|}
\hline Variabel & Karakteristik & Jumlah & Persentase \\
\hline \multirow[t]{2}{*}{ Jenis hemofilia } & A & 85 & 83,3 \\
\hline & B & 17 & 16,7 \\
\hline \multirow[t]{3}{*}{ Kelompok umur (tahun) } & $5-7$ & 22 & 21,6 \\
\hline & $8-12$ & 36 & 35,3 \\
\hline & $13-18$ & 44 & 43,1 \\
\hline \multirow[t]{3}{*}{ Keparahan penyakit } & Berat & 78 & 76,5 \\
\hline & Sedang & 21 & 20,6 \\
\hline & Ringan & 3 & 2,9 \\
\hline \multirow[t]{2}{*}{ Inhibitor } & Ya & 6 & 5,9 \\
\hline & Tidak & 96 & 94,1 \\
\hline \multirow[t]{7}{*}{ Sendi kaku } & Tidak & 75 & 73,5 \\
\hline & Ya & 27 & 26,5 \\
\hline & 1 sendi & 19 & 70,4 \\
\hline & 2 sendi & 8 & 29,6 \\
\hline & Ekstremitas atas & 9 & 33,3 \\
\hline & Ekstremitas bawah & 16 & 59,2 \\
\hline & Ekstremitas atas dan bawah & 2 & 7,5 \\
\hline \multirow{3}{*}{ Pendidikan orangtua } & Tinggi & 28 & 27,5 \\
\hline & Menengah & 42 & 41,2 \\
\hline & Rendah & 32 & 31,3 \\
\hline \multirow[t]{7}{*}{ Pendidikan anak } & Belum sekolah & 1 & 1 \\
\hline & TK & 7 & 6,9 \\
\hline & SD & 48 & 47,1 \\
\hline & SMP & 31 & 30,4 \\
\hline & SMA & 10 & 9,7 \\
\hline & Perguruan tinggi & 2 & 2 \\
\hline & Tidak sekolah & 3 & 2,9 \\
\hline \multirow[t]{2}{*}{ Penghasilan keluarga } & Kurang & 4 & 3,9 \\
\hline & Cukup & 98 & 96,1 \\
\hline \multirow[t]{2}{*}{ Tempat tinggal } & DKI Jakarta & 56 & 54,9 \\
\hline & Luar DKI Jakarta & 46 & 45,1 \\
\hline \multirow[t]{2}{*}{ Usia saat didiagnosis (bulan) } & $<24$ & 47 & 46,1 \\
\hline & $\geq 24$ & 55 & 53,9 \\
\hline \multirow[t]{2}{*}{ Lama menderita (tahun) } & $<10$ & 48 & 47,1 \\
\hline & $\geq 10$ & 54 & 52,9 \\
\hline \multirow[t]{2}{*}{ Usia perdarahan pertama kali (bulan) } & $<8$ & 46 & 45,1 \\
\hline & $\geq 8$ & 56 & 54,9 \\
\hline \multirow[t]{2}{*}{ Frekuensi perdarahan per tahun (kali) } & $<8$ & 45 & 44,1 \\
\hline & $\geq 8$ & 57 & 55,9 \\
\hline \multirow{2}{*}{ Frekuensi kunjungan ke RS per tahun (kali) } & $<14$ & 50 & 49,0 \\
\hline & $\geq 14$ & 52 & 51,0 \\
\hline
\end{tabular}

Dari semua variabel medis dan sosiodemografi yang diteliti, didapatkan hubungan kualitas hidup dengan kekakuan sendi $(\mathrm{p}<0,05)$ pada laporan anak, dengan rasio prevalensi 0,224 dan interval kepercayaan (IK) $95 \%$ 0,62-0,81 dan laporan orangtua dengan rasio prevalensi 0,345 dengan IK 95\% 0,125-0,951.

\section{Pembahasan}

Prevalensi gangguan kualitas hidup anak dengan hemofilia berdasarkan laporan anak adalah 52,9\%, sedangkan menurut laporan orangtua adalah $60,8 \%$. Penelitian lain tidak menyebutkan prevalensi gangguan 
kualitas hidup pada pasien anak hemofilia.

Total skor laporan anak dan orangtua adalah masing-masing sebesar $68,78 \pm 11,75$ dan $64,37 \pm 13,87$. Penelitian di Amerika Serikat mendapatkan rerata kualitas hidup anak dengan terapi profilaksis $84,1 \pm 14,2$ dan terapi on-demand $86,5 \pm 12,4$ menurut laporan anak, serta tidak terdapat perubahan bermakna total skor pada penelitian kohort selama 2 tahun.,

Gangguan kualitas hidup anak dengan hemofilia yang paling utama adalah fungsi fisis, sesuai dengan laporan anak dan orangtua. Gangguan fungsi fisis terjadi karena perdarahan sendi yang berulang sehingga dapat mengakibatkan nyeri, deformitas sendi, terbatasnya pergerakan sendi, dan kecacatan. Anak dengan hemofilia juga cenderung mengurangi aktivitas fisis untuk menghindari terjadinya perdarahan. Hal tersebut berdampak pada terbatasnya aktivitas anak dengan hemofilia dibandingkan anak lain seusianya.

Selain fungsi fisis, penelitian ini juga mendapatkan gangguan kualitas hidup pada fungsi sekolah. Pasien hemofilia sering izin tidak masuk sekolah akibat perdarahan yang dialaminya. Pasien tidak masuk sekolah untuk beristirahat di rumah atau berobat ke rumah sakit. Hal ini dapat menyebabkan anak hemofilia kehilangan kesempatan mencapai potensinya selama masa sekolah bahkan masa selanjutnya. Meskipun pada penelitian ini mereka menyatakan tidak ada kesulitan menyelesaikan tugas sekolah dan tidak ada kesulitan berkonsentrasi di kelas, tetapi penelitian ini tidak menilai kemampuan akademis subyek penelitian. Shapiro $\mathrm{dkk}^{7}$ menyebutkan nilai akademis anak dengan hemofilia yang sering mengalami perdarahan

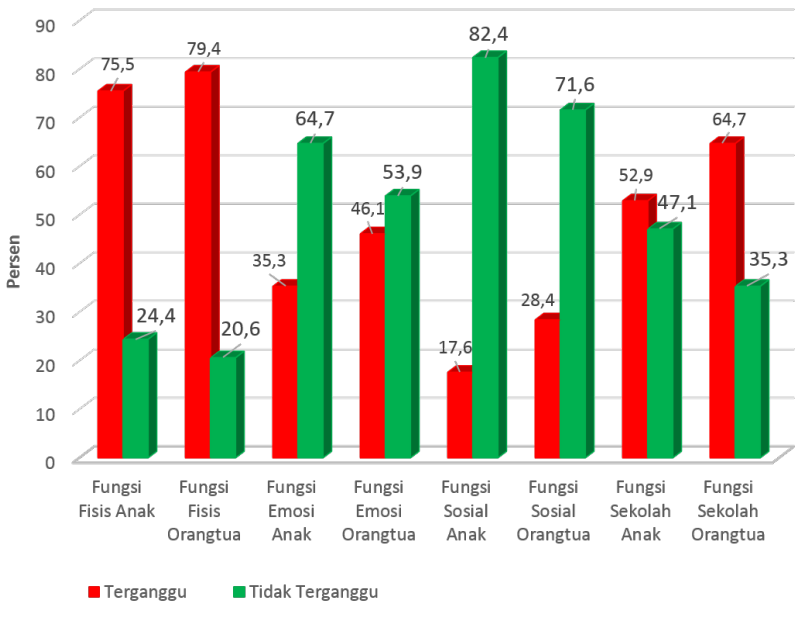

Gambar 1. Gangguan kualitas hidup anak dengan hemofilia

akan lebih rendah dibandingkan anak yang jarang mengalami perdarahan. Penurunan nilai akademis tersebut disebabkan oleh sering izin dari sekolah karena harus berobat dan keterbatasan gerak anggota tubuh.

Hasil laporan kelompok anak usia 5-7 tahun menyatakan bahwa fungsi fisis adalah domain kualitas hidup yang paling terganggu. Penelitian di Jogjakarta mendapatkan fungsi sekolah adalah kualitas hidup yang paling terganggu karena aktivitas anak di sekolah dibatasi untuk mengurangi risiko perdarahan. ${ }^{8}$ Perbedaan tersebut bisa disebabkan penelitian ini mayoritas subyeknya adalah hemofilia berat sehingga lebih rentan mengalami perdarahan yang mengganggu

Tabel 2. Kualitas hidup anak hemofilia

\begin{tabular}{lccccccccc}
\hline Dimensi & \multicolumn{9}{c}{ Laporan kualitas hidup } \\
& \cline { 2 - 10 } & \multicolumn{3}{c}{$5-7$ tahun } & \multicolumn{9}{c}{8 - 12 tahun } & \multicolumn{3}{c}{$13-18$ tahun } \\
\cline { 2 - 10 } & Anak & Orangtua & $\mathrm{p}$ & Anak & Orangtua & $\mathrm{P}$ & Anak & Orangtua & $\mathrm{p}$ \\
\hline Fisis & $56,24( \pm 18,06)$ & 59,13 & $0,592^{*}$ & 59,37 & 55,81 & $0,320^{*}$ & 63,67 & 55,82 & $0,016^{*}$ \\
& & $( \pm 17,40)$ & & $( \pm 13,71)$ & $( \pm 16,30)$ & & $( \pm 12,47)$ & $( \pm 17,11)$ & \\
Emosi & $90,90( \pm 15,71)$ & 73,86 & $0,004^{* *}$ & 73,61 & 69,86 & $0,364^{*}$ & 72,50 & 67,38 & $0,183^{*}$ \\
& & $( \pm 22,30)$ & & $( \pm 19,44)$ & $( \pm 15,09)$ & & $( \pm 16,90)$ & $( \pm 18,75)$ & \\
Sosial & $88,63( \pm 13,90)$ & 81,34 & $0,106^{* *}$ & 79,79 & 77,43 & $0,834^{* *}$ & 77,16 & 76,36 & $0,705^{* *}$ \\
& & $( \pm 15,75)$ & & $( \pm 17,22)$ & $( \pm 21,36)$ & & $( \pm 14,82)$ & $( \pm 17,13)$ & \\
Sekolah & $72,73( \pm 16,09)$ & 64,05 & $0,049^{* *}$ & 61,39 & 56,39 & $0,309^{* *}$ & 59,09 & 58,18 & $0,766^{*}$ \\
& & $( \pm 15,07)$ & & $( \pm 13,34)$ & $( \pm 18,19)$ & & $( \pm 13,95)$ & $( \pm 14,59)$ & \\
Total & 74,40 & 67,87 & $0,096^{*}$ & 67,13 & 63,64 & $0,272^{*}$ & 67,35 & 63,20 & $0,117^{*}$ \\
& $( \pm 11,82)$ & $( \pm 13,27)$ & & $( \pm 12,44)$ & $( \pm 14,24)$ & & $( \pm 10,48)$ & $( \pm 13,87)$ & \\
\hline
\end{tabular}

* uji t- tidak berpasangan, ${ }^{* *}$ uji Mann-whitney 
aktivitas fisik.

Penelitian lain yang menggunakan kuesioner Hemo-QoL menyatakan dimensi keluarga merupakan dimensi yang paling terganggu pada usia ini karena orangtua membatasi aktivitas anak. ${ }^{1,2,9,10}$ Dimensi keluarga pada kuesioner Hemo-QoL menanyakan tentang interaksi anak dengan anggota keluarga. Overprotektif orangtua terhadap anaknya bisa berdampak anak akan depresi, perilaku buruk, dan tidak mandiri. ${ }^{11}$

Pada penelitian ini, gangguan kualitas hidup anak hemofilia usia 8-12 tahun terdapat pada fungsi fisis dan sekolah. Anak usia 8-12 tahun pada penelitian di Jogjakarta juga mendapatkan gangguan fisis sebagai kualitas hidup yang paling terganggu pada pasien anak hemofilia. ${ }^{8}$ Anak-anak pada kelompok ini merasa terganggu selain karena aktivitas terbatas juga karena harus izin dari kegiatan sekolah untuk berobat ke rumah sakit.

Penelitian di Irak dan Filipina dengan kuesioner Hemo-QoL menyatakan dimensi olahraga dan sekolah adalah dimensi yang paling terganggu. ${ }^{1,10}$ Dimensi olahraga dan sekolah menanyakan apakah pasien mengalami keterbatasan dalam olahraga atau aktivitas di sekolah. Penelitian di Turki mendapatkan dimensi fisis yang paling terganggu pada kelompok usia ini. ${ }^{9}$ Hasil penelitian tersebut sesuai dengan penelitian ini. Sementara di Eropa dinyatakan yang paling terganggu adalah dimensi dukungan dan di Iran adalah dimensi teman. ${ }^{2,12}$ Pertanyaan dimensi dukungan adalah tentang bagaimana dukungan yang diperoleh pasien dari orang lain, sedangkan dimensi teman menanyakan tentang bagaimana hubungan pasien dengan temantemannya. Kedua penelitian ini ditanyakan pada fungsi sosial di kuesioner PedsQL.

Pada kelompok usia 13-18 tahun, penelitian ini mendapatkan fungsi fisis dan sekolah adalah kualitas hidup yang terganggu. Berbeda dengan penelitian di Jogjakarta yang menyatakan kualitas hidup yang paling terganggu adalah fungsi sosial. ${ }^{8}$ Penelitian di Filipina dengan menggunakan kuesioner HemoQoL menemukan kelompok remaja yang terganggu adalah olahraga dan sekolah. ${ }^{1}$ Sementara penelitian di Eropa, Irak, dan Iran mendapatkan dimensi yang terganggu adalah dimensi dukungan. ${ }^{2,10,12}$ Pada kelompok umur remaja, mereka kebanyakan sudah paham tentang penyakitnya. Namun, keterbatasan fisis pada remaja akan membuat penderita mengalami kesulitan mengikuti pelajaran di sekolah, sering izin karena harus ke rumah sakit, hilangnya kepercayaan diri, sulit bergaul dengan teman sebaya, dan hilangnya otonomi terhadap diri sendiri sehingga terganggu fungsi sosialnya. ${ }^{13}$ Pada kelompok ini, keterbatasan fisis menyebabkan gangguan kualitas hidup sehingga dukungan dari lingkungan sekitar sangat memengaruhi kehidupannya.

Tidak ada gangguan fungsi sosial di semua kelompok usia pada penelitian ini. Hal ini menunjukkan bahwa fungsi sosial atau dukungan dari lingkungan terhadap anak hemofilia yang berobat ke RSCM sudah cukup baik. Sosialisasi mengenai penyakit ini ke lingkungan pasien dapat sangat membantu pasien dalam menerima kondisinya dan diterima oleh lingkungannya.

Kualitas hidup berdasarkan laporan anak dan orangtua secara statistik berbeda pada fungsi emosi dan fungsi sekolah anak usia 5-7 tahun dan fungsi fisis anak usia 13-18 tahun. Tidak ada perbedaan antara laporan anak dan orangtua pada kelompok usia 8-12 tahun. Penelitian lain dengan menggunakan kuesioner yang sama tidak mengambil data laporan orangtua. ${ }^{2,8}$ Penelitian di Filipina dengan kuesioner Hemo-QoL mendapatkan kesesuaian laporan anak dan laporan orangtua. ${ }^{1}$

Pada rerata total fungsi emosi dan fungsi sekolah anak usia 5-7 tahun, rerata nilai laporan anak lebih tinggi daripada nilai laporan orangtua. Laporan anak tidak terdapat gangguan kualitas hidup, sedangkan laporan orangtua terdapat gangguan kualitas hidup. Perbedaan laporan anak dan orangtua dapat disebabkan persepsi yang berbeda, terutama pada hal yang bersifat subyektif. ${ }^{14}$ Pandangan orangtua dapat terpengaruh oleh perkembangan anak lain, harapan terhadap anak tersebut, stres sehari-hari dan kesehatan mental mereka sendiri. ${ }^{15}$ Orangtua yang menilai kualitas hidupnya sendiri rendah cenderung memberi penilaian yang rendah terhadap kualitas hidup anak mereka. ${ }^{16}$ Hal tersebut memberi dugaan bahwa orangtua memproyeksikan perasaannya dalam menilai kualitas hidup anak mereka. Oleh sebab itu, penilaian kualitas hidup anak kelompok usia ini perlu dinilai dari dua persepsi, yaitu laporan anak dan orangtua.

Laporan anak usia 13-18 tahun pada fungsi fisis berbeda dengan laporan orangtuanya secara statistik. Meskipun berbeda dengan pendapat orangtuanya, fungsi fisis ini dapat dibuktikan dengan pemeriksaan fisis oleh dokter. Sementara fungsi emosi, sosial dan sekolah sulit dilakukan pemeriksaan oleh dokter. Maka 
dari itu, penilaian kualitas hidup anak pada kelompok ini dapat dinilai berdasarkan salah satu laporan anak atau orangtua saja. Laporan kualitas hidup, idealnya adalah laporan anak, tetapi pada situasi tertentu saat anak tidak memungkinkan untuk mengisi kuesioner maka dapat diwakili oleh laporan orangtua. ${ }^{17}$

Faktor yang memengaruhi kualitas hidup anak dengan hemofilia berbeda-beda di setiap negara. Penelitian ini mencari faktor-faktor yang dapat memengaruhi kualitas hidup anak dengan hemofilia, yaitu derajat keparahan penyakit, inhibitor, kekakuan sendi, pendapatan orangtua, pendidikan orangtua, lokasi tempat tinggal, usia saat didiagnosis, lama menderita hemofilia, frekuensi kunjungan ke rumah sakit dan frekuensi perdarahan. Dari 10 faktor-faktor terebut, kekakuan sendi merupakan faktor yang paling memengaruhi kualitas hidup anak dengan hemofilia.

Derajat keparahan penyakit merupakan faktor yang memengaruhi kualitas hidup anak dengan hemofilia. ${ }^{5,6,10,12}$ Semakin tinggi derajat keparahannya maka semakin rentan anak hemofilia mengalami perdarahan. Begitu juga dengan adanya inhibitor yang dapat mempersulit pengobatan hemofilia. Brown $\mathrm{dkk}^{18}$ meneliti pasien hemofilia dengan inhibitor terdapat gangguan fungsi fisis yang memengaruhi aktivitas dan produktivitas. ${ }^{18}$ Sebaliknya, penelitian di Iran dan di Italia tidak menemukan hubungan inhibitor dengan kualitas hidup. ${ }^{10,19} \mathrm{Hal}$ tersebut dapat menunjukkan keberhasilan terapi untuk pasien hemofilia yang memiliki inhibitor. Penelitian ini juga tidak mendapatkan hubungan derajat keparahan hemofilia dan adanya inhibitor terhadap kualitas hidup anak hemofilia. Ini dapat disebabkan hampir seluruh subyek memiliki derajat keparahan berat atau tidak ada inhibitor, sedangkan pasien yang memiliki derajat keparahan ringan atau ada inhibitor sangat sedikit.

Pada penelitian ini nilai median usia saat didiagnosis adalah 24 bulan dengan rentang 1-156 bulan dan lama menderita hemofilia 10 tahun dengan rentang 3-18 tahun tidak memengaruhi kualitas hidup anak hemofilia. Penelitian Taha $\mathrm{dkk}^{10}$ menyebutkan usia saat didiagnosis adalah $24,36 \pm 4,22$ bulan sedangkan menurut Ziliwu ${ }^{8}$ reratanya usia 5,1 tahun. Lamanya pasien didiagnosis dipengaruhi oleh rendahnya pengetahuan keluarga mengenai hemofilia, keterbatasan biaya untuk berobat, dan belum dirutinkan skrining pada anak lelaki dengan riwayat keluarga hemofilia. Diagnosis ditegakkan saat pasien mengalami perdarahan yang serius, yaitu saat usia anak bisa berlari. Di Amerika Serikat diagnosis hemofilia lebih cepat lagi yaitu 36 bulan untuk hemofilia ringan, 8 bulan untuk hemofilia sedang, dan 1 bulan untuk hemofilia berat. Di negara tersebut dilakukan skrining pada bayi baru lahir dengan riwayat keluarga hemofilia. ${ }^{20}$ Lama menderita hemofilia tidak memengaruhi kualitas hidup karena pasien sudah menerima gangguan pembekuan darah pada dirinya.

Frekuensi terjadinya perdarahan pada anak hemofilia di Iran 4,9 $\pm 4,5$ kali per bulan dengan rerata pasien hemofilia datang ke rumah sakit 2,2 $\pm 1,9$ hari per bulan, izin dari sekolah $2,7 \pm 1,9$ hari per bulan, tidak masuk sekolah 18 hari dalam setahun dan halhal tersebut memengaruhi kualitas hidup. ${ }^{12}$ Begitu juga di Irak, perdarahan sendi lebih dari 5 kali dalam satu tahun memengaruhi kualitas hidup. ${ }^{10}$ Frekuensi terjadinya perdarahan untuk anak hemofilia derajat keparahan berat dengan terapi profilaksis $0,4 \pm 0,4$

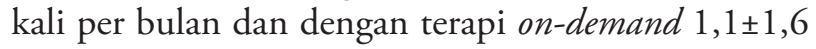
kali perbulan di Eropa. ${ }^{2}$ Pada penelitian ini median frekuensi perdarahan sendi 8 kali per tahun dengan nilai median frekuensi kunjungan ke rumah sakit adalah 14 hari dalam setahun. Penelitian lain juga melaporkan frekuensi perdarahan selama satu tahun adalah 8 kali. ${ }^{21}$ Jumlah frekuensi perdarahan pada penelitian ini diperkirakan lebih banyak karena data yang diambil hanya dari rekam medis, sedangkan tidak setiap perdarahan sendi pasien datang berobat ke rumah sakit. Meskipun tidak memengaruhi kualitas hidup secara statistik, perdarahan sendi berulang ini dapat menyebabkan kerusakan sendi bila tidak ditata laksana dengan baik.

Pasien yang berobat ke RSCM ini mendapatkan terapi on-demand sehingga pasien lebih sering mengalami perdarahan. Pasien harus sering ke rumah sakit. Pencegahan untuk terjadinya perdarahan sendi berulang adalah dengan pemberian terapi profilaksis. Sebuah penelitian menyatakan anak hemofilia berat dengan kondisi sendi yang baik yang mendapatkan terapi profilaksis dapat melakukan aktivitas seperti anak normal. ${ }^{22}$

Anak-anak hemofilia ini juga mengalami nyeri pada lokasi perdarahan. Semua anak dengan hemofilia yang mengalami kekakuan sendi terganggu kualitas hidupnya karena nyeri. Gangguan kualitas ini harus segera ditangani dengan pemberian terapi pengganti faktor VIII atau faktor IX dan fisioterapi. Fisioterapi bermanfaat untuk proses penyembuhan setelah perdarahan muskuloskeletal dan untuk pasien yang 
mengalami artropati, mengurangi nyeri serta dapat mengurangi frekuensi perdarahan dan mencegah kecacatan. Hidroterapi (fisioterapi air) maupun exercise therapy dapat memperbaiki ROM, tetapi hidroterapi lebih efektif dalam mengurangi nyeri dibandingkan exercise therapy. ${ }^{23-25}$ Anak dengan hemofilia juga harus rutin ke rehabilitasi medik untuk mengurangi gangguan kualitas hidup, yaitu keterbatasan gerak akibat perdarahan.

Pendapatan keluarga dan pendidikan orangtua berpengaruh pada kualitas hidup anak di Iran. ${ }^{12}$ Begitu juga Saxena ${ }^{26}$ dan $\mathrm{Zhou}^{27}$ mendapatkan faktor pendidikan, pendapatan keluarga, jarak lokasi tempat tinggal ke pusat pelayanan hemofilia berperan dalam kualitas hidup pasien hemofilia. ${ }^{6,26,27}$ Faktor sosioekonomi dapat menjadi penyebab stres sehingga berpengaruh pada kualitas hidup anak hemofilia. Pendidikan orangtua dapat memengaruhi pengobatan pasien, seperti orangtua harus mengetahui tanda dan cara penanganan perdarahan. Selain biaya pengobatan yang mahal, biaya transportasi untuk berobat juga perlu diperhitungkan. Penelitian ini tidak menemukan hubungan antara pendidikan orangtua, pendapatan keluarga dan lokasi tempat tinggal dengan kualitas hidup anak hemofilia. Hal ini dapat disebabkan oleh dukungan pemerintah dalam pembiayaan pengobatan, dukungan dari HMHI dan tersedianya fasilitas transportasi yang cukup memadai, seperti kereta api, transjakarta, dan transportasi online. Selain itu, edukasi kepada keluarga sesuai dengan tingkat pendidikan juga sangat penting agar keluarga memahami dan dapat memberikan dukungan kepada pasien. Kualitas hidup anak hemofilia di Filipina juga tidak terganggu masalah sosioekonomi karena adanya banyak yayasan donatur untuk anak-anak ini. ${ }^{1}$

Adanya kekakuan sendi yang menetap merupakan satu-satunya faktor yang memengaruhi kualitas hidup anak hemofilia. Sebanyak $26,5 \%$ subyek mengeluh terdapat kekakuan sendi dan mayoritas sendi ekstremitas bawah. Kekakuan sendi ini disebabkan oleh penanganan perdarahan sendi yang tidak adekuat sebelum pasien didiagnosis hemofilia. Penelitian ini mendapatkan adanya keluhan kekakuan sendi berisiko 4 (laporan anak) dan hampir 3 kali (laporan orangtua) mengganggu kualitas hidup anak hemofilia dibandingkan dengan yang tidak mengeluhkan kekakuan sendi. Penelitian di Brazil didapatkan kualitas hidup dipengaruhi adanya artropati. ${ }^{28}$ Selain terapi pengganti faktor VIII atau faktor IX, pasien hemofilia yang memiliki kekakuan sendi juga harus mendapatkan terapi fisioterapi dan rehabilitasi untuk mencegah kecacatan. ${ }^{25}$

Kelemahan penelitian ini adalah menggunakan kuesioner kualitas hidup generik, bukan kuesioner kualitas hidup yang spesifik untuk pasien hemofilia. Kuesioner PedsQL ${ }^{\mathrm{TM}} 4.0$ modul generik digunakan karena kuesioner kualitas hidup yang spesifik untuk anak hemofilia belum ada yang diterjemahkan ke dalam bahasa Indonesia dan terdapat kesulitan memperoleh kuesioner tersebut. Kuesioner generik ini tidak menggambarkan status muskuloskeletal secara spesifik, tetapi tetap dapat digunakan untuk menilai kualitas hidup anak hemofilia.

Penelitian ini menyimpulkan terdapat gangguan kualitas hidup pada sebagian besar anak dengan hemofilia di RSCM. Faktor yang memengaruhi kualitas hidup anak hemofilia adalah kekakuan sendi. Penilaian kualitas hidup untuk anak usia 5-7 tahun diperlukan laporan anak dan orangtua, sedangkan untuk usia 8-18 tahun cukup laporan anak atau orangtua saja.

\section{Daftar pustaka}

1. Espaldon AMD, Hernandez FG. Health-related quality of life assessment in Filipino children with hemophilia aged 4 To 16 years in a tertiary hospital. J Hematol Thromb Dis 2014;2:1-6.

2. Gringeri A, Mackensen SV, Auerswald G, Bullinger M, Garrido RP. Health status and health-related quality of life of children with hemophilia from six West European countries. Haemophilia 2004;10:26-33.

3. Varni JW, Seid M, Skarr D, Burwinkle TS. Health status assessment project. Data Insight Report Children's Health Assessment Project 2002;10:1-12.

4. Gatot D, Moeslichan S. Gangguan pembekuan darah yang diturunkan. Dalam: Permono HB, Sutaryo, Ugrasena IDG, Windiastuti E, Abdulsalam M, penyunting. Buku ajar hematologi. Edisi ke-3. Jakarta: Badan Penerbit IDAI; 2010. h. 174-7.

5. Poon JL, Zhou ZY, Doctor JN, Wu J, Ullman MM, Ross C, dkk. Quality of life in haemophilia A: hemophilia utilization group study Va (HUGS-Va). Haemophilia 2012;5:699-707.

6. Poon JL, Doctor JN, Nichol MB. Longitudinal changes in health-related quality of life for chronic disease: an example in hemophilia A. J Gen Intern Med 2014;29:760-6.

7. Shapiro AD, Donfield SM, Lynn HS, dkk. Defining the impact of hemophilia: the academic achievement in children 
with hemophilia study. Pediatrics 2001;108:1-6.

8. Ziliwu TK. Kualitas hidup anak dengan hemofilia dan faktorfaktor yang mempengaruhinya di bagian IKA RSUP Dr. Sardjito Yogyakarta [Tesis]. [Yogyakarta]: Universitas Gajah Mada; 2012.

9. Mercan A, Sarper N, Inanır M, dkk. Hemophilia-specific quality of life index (Haemo-QoL and Haem-A-QoL questionnaires) of children and adults: result of a single center from Turkey. Pediatr Hematol Oncol 2010; 27:449-61.

10. Taha MY, Hassan MK. Health-related quality of life in children and adolescents with hemophilia in Basra, Southern Iraq. J Pediatr Hematol Oncol 2014;36:179-84.

11. Holmbeck GN, Johnson SZ, Wills KE, dkk. Observed and perceived parental overprotection in relation to psychosocial adjustment in preadolescents with a physical disability: the mediational role of behavioral autonomy. J Consult Clin Psychol 2002;70:96-100.

12. Bagheri S, Beheshtipoor N, Rambod M, Karimi M, Zare N, Hashemi F. The quality of life of children with hemophilia in Shiraz, Iran. IJCBNM 2013;1:110-20.

13. Gringeri A, Mackensen SV. Quality of life in hemophilia. Hemophilia. 2008;14:19-25.

14. Janse AJ, Sinnema G, Uiterwaal CSPM, Kimpen JLL, Gemke RJBJ. Quality of life in chronic illness: children, parents and paediatricians have different, but stable perceptions. Acta Paediatr 2008;97:1118-24.

15. Eiser C. Children's quality of life measurement. Arch Dis Child 1997;77:350-4.

16. Eiser C, Eiser JR, Stride CB. Quality of life in children newly diagnosed with cancer and their mothers. Health Qual of Life Outcomes 2005;3:29-34.

17. Varni JW, Limbers CA, Burwinkle TM. How young can children realibility and validity self-report their health-related quality of life?: an analysis of 8,591 children across age subgroup with the PedsQL ${ }^{\mathrm{TM}} 4.0$ generic core scales. Health Qual of Life Outcome 2007;5:1-13.

18. Brown TM, Lee WC, Joshi AV, Pashos CL. Health-related quality of life and productivity impact in haemophilia patients with inhibitors. Haemophilia 2009;15:911-7.
19. Scalone L, Mantovani LG, Mannucci PM, Gringeri A. Quality of life is associated to the orthopaedic status in haemophilic patients with inhibitors. Haemophillia 2006;12:154-62.

20. Centers for disease control and prevention. Hemophilia: data and statistics. [Diakses tanggal 1 November 2016]. Didapat dari: https://www.cdc.gov/ncbddd/hemophilialdata.html.

21. Trippoli S, Vaiani M, Linari S, Longo G, Morfini M, Messori A. Multivariate analysis of factors influencing quality of life and utility in patients with hemophilia. Haematologica 2001;86:722-8.

22. Net JVD, Vos RC, Engelbert RHH, Berg MHVD, Helders PJM, Takken T. Physical fitness, functional ability and quality of life in children with severe haemophilia: a pilot study. Haemophilia 2006;12:494-99.

23. Mazloum V, Rahnama N, Khayambashi K. Effects of therapeutic exercise and hydrotherapy on pain severity and knee range of motion in patients with hemophilia: a randomized controlled rial. Int J Prev Med 2014;5:83-8.

24. Mazloum V, Khayabash KH, Rahnama N. Comparing the effects of therapeutic exercise and hydrotherapy on pain severity and knee range of motion in patients with hemophilia: a randomized controlled trial. Armaghane danesh 2013;18:430-41.

25. Heijnen L, Buzzard BB. The role of physical therapy and rehabilitation in the management of hemophilia in developing countries. Semin Thromb Hemost. 2005;31:5137.

26. Saxena K. Barriers and perceived limitations to early treatment of hemophilia. J Blood Med 2013;4:49-56.

27. Zhou ZY, Riske B, Forsberg AD, Ullman M, Baker JR, Koerper MA, dkk. Self-reported barriers to hemophilia care in people with factor VIII deficiency. Am J Prev Med 2011;41:346-53.

28. Ferreira AA, Leite ICG, Teixeira MTB, Correa CSL, Cruz DTD, Rodrigues DOW, dkk. Health-related quality of life in hemophilia: result of the hemophilia- specific quality of life index (Haem-A-QoL) at Brazilian blood center. Rev Bras Hematol hemoter 2013;35:314-8. 